\title{
Hydrobiologia
}

\section{What traits underpin the successful establishment and spread of the invasive water bug Trichocorixa verticalis verticalis? \\ --Manuscript Draft--}

\begin{tabular}{|c|c|c|}
\hline Manuscript Number: & \multicolumn{2}{|l|}{ HYDR-D-15-00385R3 } \\
\hline Keywords: & \multicolumn{2}{|c|}{ corixids; Trichocorixa; Sigara; Alien species; expansion; traits } \\
\hline \multicolumn{3}{|l|}{$\begin{array}{l}\text { Corresponding Author Secondary } \\
\text { Information: }\end{array}$} \\
\hline Corresponding Author's Institution: & \multicolumn{2}{|l|}{ Universidad de Murcia } \\
\hline \multicolumn{3}{|l|}{ First Author Secondary Information: } \\
\hline \multirow[t]{6}{*}{ Order of Authors: } & \multicolumn{2}{|l|}{ José Antonio Carbonell } \\
\hline & \multicolumn{2}{|l|}{ Andrés Millán } \\
\hline & \multicolumn{2}{|l|}{ Andy J Green } \\
\hline & \multicolumn{2}{|l|}{ Vanessa Céspedes } \\
\hline & \multicolumn{2}{|l|}{ Cristina Coccia } \\
\hline & \multicolumn{2}{|l|}{ Josefa Velasco } \\
\hline \multirow{4}{*}{ Funding Information: } & $\begin{array}{l}\text { Ministerio de Educación, Cultura y } \\
\text { Deporte } \\
\left(11^{\circ} \text { Arquímedes young investigators }\right. \\
\text { award) }\end{array}$ & Vanessa Céspedes \\
\hline & $\begin{array}{l}\text { Consejería de Innovación, Ciencia y } \\
\text { empresa, Junta de Andalucía } \\
\text { (P10-RNM-6262) }\end{array}$ & Andy J Green \\
\hline & $\begin{array}{l}\text { Ministerio de Agricultura, Alimentación y } \\
\text { Medio Ambiente } \\
\text { (Atlas y libro rojo de los coleópteros } \\
\text { acuáticos de España peninsular) }\end{array}$ & Andrés Millán \\
\hline & $\begin{array}{l}\text { Ministerio de Economía y Competitividad } \\
\text { (CGL2010-15378) }\end{array}$ & Josefa Velasco \\
\hline Abstract: & \multicolumn{2}{|c|}{$\begin{array}{l}\text { The introduction of exotic species has a major impact on a wide range of ecosystems, } \\
\text { especially in aquatic ecosystems. Trichocorixa v. verticalis (Fieber, 1851), an } \\
\text { euryhaline aquatic hemipteran native North America, has occurred as an exotic } \\
\text { species in the Iberian Peninsula since at least } 1997 . \text { In this study, we compared } \\
\text { several physiological and biological traits (salinity tolerance of the different } \\
\text { developmental stages, thermal tolerance, fecundity and dispersal ability) in the alien } \\
\text { species and three native, syntopic corixid species (Sigara lateralis, Sigara scripta and }\end{array}$} \\
\hline
\end{tabular}


Sigara selecta), to determine which traits may explain its invasion success.

Trichocorixa verticalis was the species most resistant to high conductivity at the egg stage, while S. selecta showed the highest halotolerance as adults. The invader had the highest upper thermal limit and a much higher fecundity than Sigara species. Wing morphometry suggested that $T$. verticalis may be a stronger flier than the native species. Our findings provide an example of how functional and ecological niche interactions among alien and native species can help predict impacts of invasion on aquatic communities.

Response to Reviewers:

\section{Dear Editor,}

Please find enclosed a revised version of the ms "What traits underpin the successful establishment and spread of the invasive water bug Trichocorixa verticalis verticalis?" (Ref.: HYDR-D-15-00385) by Carbonell et al.

We have followed the suggestions of the editor, which we found helpful and insightful. We are now resubmitting a revised version, which we would like you to consider of publication in Hydrobiologia.

In the letter which follows, we indicate how we have responded to the comments (the responses have been written between -dashes-). We hope that our ms is now acceptable for publication. If not, we are ready to make whatever further changes are required.

Thank you for considering our work to be published in Hydrobiologia.

Sincerely, JA Carbonell

\section{COMMENTS TO THE AUTHOR:}

All earlier comments have been adequately addressed and I am pleased to inform you that this manuscript may be accepted for publication, pending these minor editorial comments and the final assessment by the EIC.

23-24 change "a good example" to "an example" for a more unbiased representation.

186-7 Both species are different in colouration, size (S. lateralis is bigger) and form ( $T$. v. verticalis is more parallel shaped) (Günter, 2004; Nieser et al., 1994). Change to "The two species are different in coloration, size (S. lateralis is bigger) and shape, T. v. verticalis being more??? [elongated? "parallel shaped" is not a term used in English] (Günter, 2004; Nieser et al., 1994).

336 Differences between T. v. verticalis nymphs and adults in survival time... Change to: "Differences in survival time between T. v. verticalis nymphs and adults..."

436 that allowing - change to "that allow".

477 Resistant structures- perhaps 'resting stages'? It is unclear that resistant structures refers to any biological entity.

- In the new version of the manuscript we have included the suggested changes of the editor. Track changes (in yellow) has been used to speed up review process. -

\section{2,4 what is ramping programs?}

- A ramping program performs a dynamic temperature change along time (in our case $1{ }^{\circ} \mathrm{C}$ min-1) until the end points (positive or negative). To reduce possible confusion the sentence has been rewritten from "employing a dynamic method using two ramping programs with a rate of temperature change of $1^{\circ} \mathrm{C}$ min-1, from acclimation temperature $\left(20^{\circ} \mathrm{C}\right)$ until the upper $\left(70^{\circ} \mathrm{C}\right)$ or lower temperature limit $\left(-45^{\circ} \mathrm{C}\right)$ " to "employing a dynamic method using a ramping rate of $\pm 1^{\circ} \mathrm{C}$ min- 1 , from acclimation temperature $\left(20^{\circ} \mathrm{C}\right)$ until the upper $\left(70^{\circ} \mathrm{C}\right)$ or lower temperature limit $\left(-45^{\circ} \mathrm{C}\right)$ " ( $\mathrm{L} 252-$ 
TITLE: What traits underpin the successful establishment and spread of the invasive water bug Trichocorixa verticalis verticalis?

AUTHORS: J.A. Carbonell ${ }^{1}$, A. Millán ${ }^{1}$, A.J. Green ${ }^{2}$, V. Céspedes ${ }^{2}$, C. Coccia $^{2} \&$ J. Velasco ${ }^{1}$

1. Departamento de Ecología e Hidrología, Universidad de Murcia. Murcia, Spain.

2. Departament of Wetland Ecology, Estación Biológica de Doñana-CSIC. Sevilla, Spain. 8

Corresponding author: joseantonio.carbonell@um.es

\section{SUMMARY}

The introduction of exotic species has a major impact on a wide range of ecosystems, especially in aquatic ecosystems. Trichocorixa v. verticalis (Fieber, 1851), an euryhaline aquatic hemipteran native North America, has occurred as an exotic species in the Iberian Peninsula since at least 1997. In this study, we compared several physiological and biological traits (salinity tolerance of the different developmental stages, thermal tolerance, fecundity and dispersal ability) in the alien species and three native, syntopic corixid species (Sigara lateralis, Sigara scripta and Sigara selecta), to determine which traits may explain its invasion success. Trichocorixa verticalis was the species most resistant to high conductivity at the egg stage, while $S$. selecta showed the highest halotolerance as adults. The invader had the highest upper thermal limit and a much higher fecundity than Sigara species. Wing morphometry suggested that $T$. verticalis may be a stronger flier than the native species. Our findings provide an example of how functional and ecological niche interactions among alien and native species can help predict impacts of invasion on aquatic communities. 
KEYWORDS: corixids, Trichocorixa, Sigara, alien species, expansion, traits.

INTRODUCTION

The introduction of alien species has a major impact on a wide range of ecosystems and is a major cause of global change (Ricciardi, 2006). Alien invaders are of particular concern in aquatic ecosystems (Dudgeon et al., 2006), especially in protected areas region in future years (Guareschi et al., 2013). 
51 The distribution of T. v. verticalis in the introduced range in south-west Spain has been expanding in recent years (Carbonell et al., 2012a; Guareschi et al., 2013), especially in and around Doñana, where it has become the dominant breeding corixid at several sites, especially in brackish and saline permanent water bodies (Rodríguez-Pérez et al., 2009; Van de Meutter et al., 2010b).

The invasion process can be divided into a series of stages (transport, establishment, spread and impact) and at each stage there are barriers that need to be overcome for a species or population to pass on to the next stage (Blackburn et al., 2011). In the first phase of the invasion process, the species must travel from its native range to a new ecosystem (transport). In the second phase it must survive, grow and reproduce under the new environmental conditions (establishment). In the third phase (spread), it must acquire a high rate of population growth, invading new regions through active and/or passive dispersal (including possible dispersal by migratory birds as eggs, see Figuerola et al., 2003) and short generation time. Finally, in the last phase, the alien species must alter the structure and functioning of the invaded ecosystem (impact) (Parker et al., 1999) through interactions with other species or ecosystem engineering.

The pathway of entry for T. v. verticalis is unknown, but some authors have suggested that it was facilitated by the introduction of American fishes Gambusia affinis and/or Fundulus heteroclitus (Sala \& Boix, 2005; L’Mohdi et al., 2010), while others have suggested it might have been transported in ballast water (Guareschi et al., 2013). Some biological and ecological traits of $T$. v. verticalis relevant to its invasiveness have been studied in its native (Tones, 1977; Kelts, 1979; Simonis, 2013) or invasive range (Coccia et al., 2013; 2014). Salinity tolerance was compared between adults of $T . v$. 
verticalis and three native Sigara species (Van de Meutter et al., 2010b), concluding that S. selecta outperforms $T$. v. verticalis in terms of salinity tolerance, and that therefore its invasion success cannot simply be explained only by its high halotolerance as an adult. Thermal tolerance has also been studied (Coccia et al., 2013), finding that T. v. verticalis presents greater thermal plasticity than the native Sigara lateralis, suggesting that this may facilitate its spread in the future, since $T$. v. verticalis may be more able to positively respond to climate change than native species. Furthermore, Van de Meutter et al. (2010a) studied interactions between T. v. verticalis with the aquatic macroinvertebrate community and found indirect evidence that the native $S$. selecta has been displaced by T. v. verticalis, especially in artificial saline water bodies (RodríguezPérez et al., 2009). There is similar evidence for displacement of S. selecta by $T$. $v$. verticalis in Moroccan salt-pans (L’Mohdi et al., 2010). Other studies have focused on interactions of T. v. verticalis and Sigara spp. with predators and parasites in the Doñana area (Coccia et al., 2014; Sánchez et al. 2015), finding that in freshwaters the invasive species is more sensitive to predation by Odonata larvae and to parasitism by aquatic mites than the native species.

However, no previous comparative information exists on reproductive rates, dispersal ability or salinity tolerance of eggs or nymphs. There is a need for an integrative study considering the major traits involved in the spread and establishment phase of $T . v$. verticalis and how these traits influence the interactions (competition, coexistence) with native corixids. In the present study, we combined field distribution and experimental data on T. v. verticalis and three native corixid species to address the major physiological and biological traits related with the establishment and spread phases of the T. v. verticalis invasion. We aimed to identify traits that enhance the potential of this 
alien species to outcompete native species and that explain its distribution and recent expansion in southern Spain, particularly in mesosaline waters. We compared physiological, life history and morphological traits among $T$. v. verticalis and the coexisting Sigara species (corixids with a similar size) along the salinity gradient at which they occur: Sigara lateralis (Leach, 1817) and S. scripta (Rambur, 1840) in subsaline and hyposaline waters and S. selecta (Fieber, 1848) in mesosaline waters. We studied salinity tolerance and thermal tolerance as determinants of the ability to tolerate a wide range of abiotic conditions (Alonso \& Camargo, 2003, 2004; Gérard et al., 2003). We also studied oviposition rate, hatching time and hatching success as measures of reproductive capacity and the recruitment of new individuals (Richards, 2002), as well as potential flight dispersal ability related to the mechanism for active dispersal and spread (Sakai et al., 2001). We studied thermal tolerance and fecundity traits at two salinity concentrations representing the extremes of the gradient where the alien species coexists with native species, to test if these traits change with salinity, since exposure to different salinities can influence thermal tolerance (Sánchez-Fernández et al., 2010; Arribas et al., 2012; Coccia et al., 2013) and fecundity (Gelin et al., 2001; CastroLongoria, 2003) in aquatic Coleoptera and Hemiptera. We hypothesised that the establishment success of $T$. v. verticalis in mesosaline waters would be mediated by wide environmental tolerance and a high reproductive rate that exceeds that of the native $S$. selecta. On the other hand, we hypothesized that, in hyposaline waters the reproductive ability of $T . v$. verticalis will be lower than that of native species. Finally, we hypothesised that a high active dispersal capacity could contribute to rapid spread of this alien species.

\section{MATERIALS AND METHODS}


Study species

Trichocorixa $v$. verticalis is a euryhaline species which can inhabit low salinity waters, but prefers coastal brackish and saline lentic waterbodies, and is even recorded in the open sea (Hutchinson, 1931). In the invaded range, it breeds in permanent water bodies with salinity exceeding $10 \mathrm{~g} \mathrm{~L}^{-1}$ (Rodríguez-Pérez et al., 2009).

The three Sigara species show different habitat preferences with regard to salinity, ranging from freshwater to saline (see also our results). Sigara lateralis, widely spread in the Palaearctic Region (Aukema \& Rieger, 1995), is an opportunistic species frequently inhabiting temporary freshwater pools (Millán et al., 1988; Boda \& Csabai, 2009; Carbonell et al., 2011). It has been described as a migratory species (Macan, 1976; Weigelhofer et al., 1992) and is typically captured by light-trapping more often than any other aquatic insect (Popham, 1964; Weigelhofer et al., 1992). Sigara scripta, a mainly circum-Mediterranean species (Aukema \& Rieger, 1995), inhabits freshwater or hyposaline ponds and stream pools (Carbonell et al., 2011), as well as coastal brackish waters (Moreno et al., 1997; Van de Meutter et al., 2010b). Sigara selecta, distributed in Western Europe and Northern Africa (Aukema \& Rieger, 1995), inhabits coastal lentic brackish and saline water bodies (Nieser et al., 1994).

\section{Conductivity niche analysis}

In the Iberian Peninsula, T. v. verticalis coexists with native Sigara species throughout its conductivity range. The realised conductivity niches of adults and nymphs of the study species were analysed in order to determine the conductivity range where species can coexist, with overlapping niches. When sampling, we follow a multihabitat protocol 
to estimate relative abundances for adults (232 localities) and nymphs (92 localities) of the four species in the Iberian Peninsula. The information was gathered from the Aquatic Ecology Research Group’s Biodiversity dataset at the University of Murcia, and the Wetland Ecology Department's dataset at the EBD-CSIC, Seville (Coccia et al., unpublished data). The realised conductivity niche of the four species was assessed by an Outlying Mean Index (OMI) analysis (Dolédec et al., 2000), using the niche procedure in ADE-4 package (Thioulouse et al., 1997). The OMI, or species marginality index, measures the distance between the mean habitat conditions used by species (the species centroid), and the mean habitat conditions of the sampling area (the origin of the niche hyperspace). OMI analysis places species along habitat gradients, in this case a conductivity gradient. The position of the species depends on their niche deviation from a reference point, which represents neither the mean nor the most abundant species but rather a theoretical ubiquitous species that tolerates the most general habitat conditions (i.e., that is uniformly distributed among habitat conditions). This analysis also calculates niche breadth (tolerance) as a measure of the amplitude in the distribution of each species along the sampled gradient. The species abundance and conductivity were logarithmically transformed prior to analysis, to reduce data variability. This analysis was performed in R v 3.0.2 for Windows ( $\mathrm{R}$ Core Team, 2014).

Evaluating tolerance to abiotic conditions: salinity and thermal tolerance

\section{$\underline{\text { Salinity tolerance tests }}$}

Salinity tolerance tests for adults, nymphs and eggs of $T$. v. verticalis and $S$. lateralis were performed in the laboratory in the spring of 2013 following the methodology of 
Carbonell et al. (2012b), whose data for S. scripta and S. selecta from spring 2011 were used in this study. In this earlier study, individuals of both species (S. scripta and $S$. selecta) were collected in the same localities as individuals used for the current study in 2013 (see Table 1). Those sites represent the optimum salinity for the species (Carbonell et al., 2012b) and their natural conditions have not changed significantly in recent years.

For S. lateralis and T. v. verticalis, about 200 adults and nymphs were collected from two different localities (Table 1) with a hand net and transported in containers with their original water to the laboratory. These two species are easy to distinguish from each other in the field. Both species are different in colouration, size (S. lateralis is bigger) and form, T. v. verticalis being more elongated (Günter, 2004; Nieser et al., 1994). Before their use in tolerance tests, adults from each species were kept for two days in a 5- $\mathrm{L}$ aquarium with their original water, held at $20-22^{\circ} \mathrm{C}$ to acclimatize them to laboratory conditions, and fed daily with frozen chironomid larvae. Nymphs were kept in the same laboratory conditions, and fed with dried microscopic algae (Tetraselmis chuii) and frozen chironomid larvae. Finally, to obtain eggs, males and females of each species were placed in aquaria and allowed to lay eggs on a plastic mesh that was removed daily and transferred to test vials.

Five treatments were used in conductivity tests: $0.6,16,37,74$ and $100 \mathrm{mS} \mathrm{cm}^{-1} \mathrm{EC}$, which correspond to $0.3,10,25,50$ and $75 \mathrm{~g} \mathrm{~L}^{-1}$ respectively. The solutions were prepared by dissolving marine salt (Ocean Fish, Prodac®. Citadella Pd, Italy) in distilled water. After acclimatizing, adults were placed individually in $50 \mathrm{~mL}$ aerated plastic vials filled with solutions in a controlled-temperature chamber $\left(20 \pm 1{ }^{\circ} \mathrm{C}, 12 \mathrm{~h}\right.$ 
light: 12 h dark; no food) (Carbonell et al., 2012b). A total of 60 adults from each species were used in the experiment (ten individuals $\mathrm{x}$ five conductivities + ten control individuals in filtered $-1.2 \mu \mathrm{m}$ vacuum filter - water from sampling sites). Survival was monitored daily for one week or until control mortality rate reached $20 \%$. The same number of nymphs and eggs from each species were used as for adults. Nymphs (third or fourth instars) and eggs (less than 24 hours old) were placed individually in glass vials (5 mL solution) under the same experimental conditions as adults. The nymph's survival was monitored at $24 \mathrm{~h}$ and $48 \mathrm{~h}$, and eggs were monitored until hatching or up to 25 days. Hatching time and success of eggs was quantified. Interspecific differences in survival time of adults and nymphs and the hatching time of eggs, as well as differences in survival after $48 \mathrm{~h}$ between adults and nymphs, were analysed for each species using Kruskal - Wallis non-parametric tests because these variables did not meet residual normality assumptions (Shapiro-Wilks test, $\mathrm{p}<0.05$ ). Fisher's post-hoc LSD t-tests were applied using a Bonferroni correction for multiple comparisons to identify significant differences in the response variables among species and conductivity treatments (Quinn \& Keough, 2002). Analyses were performed using SPSS for Windows, Rel. 15.0.1. 2006. Chicago: SPSS Inc.

\section{Thermal tolerance tests}

Thermal tolerance of $T . v$ verticalis was compared experimentally with the three Sigara species with which it can coexist at hyposaline conditions $\left(16 \mathrm{mS} \mathrm{cm}^{-1}=10 \mathrm{~g} \mathrm{~L}^{-1}\right)$, and only with $S$. selecta at mesosaline conditions $\left(37 \mathrm{mS} \mathrm{cm}^{-1}=25 \mathrm{~g} \mathrm{~L}^{-1}\right)$. Thermal tolerance tests were carried out to determine upper and lower thermal limits of adults acclimated at the two selected conductivity treatments. 
Adults were collected from the field in autumn 2013 at the same localities as previous experiments (Table 1) and were directly transferred to 5-L aquaria at experimental conductivities in the laboratory, then kept for $72 \mathrm{~h}$ at $20^{\circ} \mathrm{C}$ in a controlled-temperature chamber. Organisms were fed with frozen chironomid larvae during the first 48 hours, but no food was provided for $24 \mathrm{~h}$ prior to determination of thermal limits because gut contents can modify freezing temperature (Chown \& Nicholson, 2004). Following the acclimation period, 80 individuals (40 males and 40 females) of each species were removed from each conductivity treatment and divided into two sub-groups of 40 individuals (20 males and 20 females): one used to measure upper thermal limits (UTL) and the other to measure lower thermal limits (LTL). Although a number of potential end-points exist for tolerance both to heat and cold (Chown \& Nicolson, 2004), we considered the supercooling point (SCP) or point before the freezing temperature (Wilson et al., 2003) as LTL and the heat coma point or point of paralysis prior to death and preceded by spasmodic leg movement as the UTL (Chown \& Terblanche, 2007). Although death was easily identifiable in upper thermal tolerance experiments, defining lower lethal limits proved more difficult because individuals exhibiting total paralysis would revive and recover full or partial locomotor abilities shortly after the end of the exposure period. Thus, SPC was selected as the comparable objective variable among species for LTL, since freezing temperature is largely unaffected by cooling rate (Chown \& Nicholson, 2004).

Prior to testing, individuals were removed from their acclimation aquaria, washed with distilled water, dried on absorbent paper, then placed upside down tied by their wings onto a clean, dry rectangular piece of pottery using a small piece of adhesive tape. This procedure keeps individuals motionless during the experiment. Tests were carried out in 
air in a controlled-temperature chamber (BINDER MK53. BINDER GmbH, Tuttlingen, Germany), employing a dynamic method using a ramping rate of $\pm 1{ }^{\circ} \mathrm{C} \min ^{-1}$, from acclimation temperature $\left(20^{\circ} \mathrm{C}\right)$ until the upper $\left(70^{\circ} \mathrm{C}\right)$ or lower temperature limit $(-45$ $\left.{ }^{\circ} \mathrm{C}\right)$. An identical ramping rate was employed in previous studies, thus allowing comparison amongst treatments and taxa (Calosi et al., 2008; Sánchez-Fernández et al., 2010; Arribas et al., 2012; Coccia et al., 2013). To determine UTL and LTL, the body surface temperature was measured throughout the experiment using an infrared video camera (FLIR A325sc. FLIR Systems Inc., Wilsonville, USA) coupled to the climatic chamber, at a distance of c. $0.4 \mathrm{~m}$ from the insects. The infrared camera converted body surface radiation into a thermal pattern and was capable of detecting temperature differentials of $0.1{ }^{\circ} \mathrm{C}$. As a supplement, the insects were recorded throughout the experiment using a video camera (Sony DCR-DVD110E. Sony Co., Tokyo, Japan) synchronised with the infrared camera, From video images, the moment at which movement of legs ceased was determined and the body surface temperature at that moment was obtained from infrared thermal images. Infrared recordings were analysed with ThermaCAM ${ }^{\mathrm{TM}}$ Researcher Pro 2.10 software. Differences in UTL and LTL were examined by ANOVA considering acclimation conductivity, species and sex as fixed factors, together with their interactions. As preliminary analyses showed no differences between sexes (UTL: $F=0.01, P=0.932 ; \mathrm{LTL}: F=1.21, P=0.273$ ), sex was removed from further analysis.

\section{Evaluating the reproductive capacity: species fecundity tests}

Fecundity tests were carried out on adults of the four species in autumn 2013. The oviposition rate of $T . v$ verticalis was compared experimentally with the three Sigara 
species with which it can coexist at hyposaline conditions $\left(16 \mathrm{mS} \mathrm{cm}^{-1}\right)$, and only with S. selecta at mesosaline conditions $\left(37 \mathrm{mS} \mathrm{cm}^{-1}\right)$.

The oviposition rate of species (expressed in eggs day ${ }^{-1}$ ) was determined under laboratory conditions $\left(20 \pm 2{ }^{\circ} \mathrm{C}, 12 \mathrm{~h}\right.$ light: $12 \mathrm{~h}$ dark). Adults were collected from the field (Table 1) and 10 pairs (one female and one male) of each species were directly transferred to $500 \mathrm{ml}$ aquaria (one pair per aquarium) filled with salt solutions and fed daily with frozen chironomid larvae. A piece of plastic mesh was placed in each aquarium as an oviposition site. Egg production was monitored daily until the female died. If the male died before the female, it was replaced. Eggs laid during the first two days were excluded before calculating oviposition rate, to minimise the effect of any females carrying eggs when collected in the field. Differences in oviposition rate were examined by ANOVA, considering acclimation conductivity and species as fixed factors.

\section{Evaluating dispersal ability: wing morphometry measures}

Morphometric measurements of metathoracic wings (flight wings) were taken in order to compare active dispersal ability among study species. Measurements were taken from individuals collected in the field and preserved in $100 \%$ alcohol at $-20^{\circ} \mathrm{C}$ (Arribas et al., 2012). Forty individuals (20 males and 20 females) of each species were dried at $60{ }^{\circ} \mathrm{C}$ in an oven (JP Selecta Prebatem. JP Selecta, Barcelona, Spain) for 24 h, and dry weight was measured using a digital balance (Sartorius BP221S. Sartorius AG, Goettingen, Germany) to $\pm 0.0001 \mathrm{~g}$. Measured individuals were kept in hot water (about $80^{\circ} \mathrm{C}$ ) for 1 minute to rehydrate them and facilitate manipulation of the wings. After rehydration, the left metathoracic wing was removed, teased open, stained with chlorazol black 
(Martínez, 2002), and mounted in 50\% dimethyl hydantoin formaldehyde (DMHF) on a microscope slide restoring their natural size and shape. Wings and individuals were photographed under a Zeiss Stemi 2000C Trinocular Zoom Stereomicroscope (Zeiss, Thornwood, NY, USA), and subsequently length, width and area of the wing were measured using a Spot Insight Firewire digital camera (Spot Imaging Solutions, Sterling Heights, MI, USA) and associated software. Raw measures of body mass and wing were used to derive wing loading (body mass/wing area) and wing aspect ratio (wing length/wing width) (Gibb et al., 2006; Arribas et al., 2012). For both indices, species and sex, together with their interaction, were considered as fixed factors in ANOVA. All ANOVA analyses were conducted using SPSS for Windows, Rel. 15.0.1. 2006. Chicago: SPSS Inc.

\section{RESULTS}

\section{Realised conductivity niche}

OMI results revealed an overlapping conductivity niche among adults of the study species (Fig. 1a). The exotic species showed a wide niche, similar to that of S. selecta although with a lower conductivity optimum, occurring from subsaline to hypersaline waters (1.03-120 mS cm $\left.\mathrm{cm}^{-1}\right)$, but was more frequent in mesosaline waters. Sigara selecta had a niche in the upper part of the conductivity gradient, being an exclusive inhabitant of brackish and saline waters (16.6-200 $\left.\mathrm{mS} \mathrm{cm}^{-1}\right)$. Sigara scripta adults occurred along a broad conductivity gradient $\left(0.25-41.6 \mathrm{mS} \mathrm{cm}^{-1}\right)$, with a niche midway in the overall conductivity range. Sigara lateralis presented the lowest conductivity tolerance, occurring from fresh to hyposaline waters $\left(0.15-33.6 \mathrm{mS} \mathrm{cm}^{-1}\right)$. Nymphal stages presented less conductivity tolerance and lower niche breadth than conspecific adults, 
although with similar overlap in niches among species along the conductivity gradient (Fig. 1b).

\section{Salinity tolerance}

There were significant differences in salinity tolerance among species $(H=53.49, p<$ 0.001) (Figure 2 and Table S1.1). Conductivity had significant effects on adult and nymph survival times, and egg hatching time. Trichocorixa $v$. verticalis adults survived until $37 \mathrm{mS} \mathrm{cm}^{-1}$, but did not show significant differences in survival time with $S$. lateralis or S. scripta at lower conductivities $\left(0.6\right.$ and $\left.16 \mathrm{mS} \mathrm{cm}^{-1}\right)$. Adults of the most tolerant species, $S$. selecta, were able to survive along the entire conductivity gradient with a higher survival time than other species (Figure 2a).

Differences between $T$. v. verticalis nymphs and adults in survival time were not significant $(H=3.34, p=0.068)$. The same pattern was found for $S$. lateralis $(H=2.12$, $p=0.146)$ and $S$. scripta $(H=0.042, p=0.838)$. Only $S$. selecta $(H=16.33, p<0.001)$ showed significant differences between nymphs and adults in survival time. Nymphs of T. v. verticalis and $S$. selecta survived up to $37 \mathrm{mS} \mathrm{cm}^{-1}$ and did not differ significantly in survival time at that conductivity (Figure 2b). Nymphs of S. lateralis and S. scripta survived until $16 \mathrm{mS} \mathrm{cm}^{-1}$, although $S$. lateralis was significantly less tolerant than other species at that conductivity.

Trichocorixa $v$. verticalis eggs showed the highest conductivity tolerance, being the only species hatching up to $74 \mathrm{mS} \mathrm{cm}^{-1}$, when mean hatching time was 20.9 days (Figure 2c). Their hatching success was high (80\%) at lower conductivities, decreasing with increasing conductivity (Table 2). Eggs of S. selecta hatched with $100 \%$ success at 
conductivities up to $37 \mathrm{mS} \mathrm{cm}^{-1}$, showing no significant differences in hatching time with T. v. verticalis eggs (Table 2). Eggs of S. lateralis and S. scripta hatched until 16 $\mathrm{mS} \mathrm{cm}{ }^{-1}, S$. lateralis showing the shortest hatching time and the highest hatching success at lower conductivities $\left(0.6\right.$ and $\left.16 \mathrm{mS} \mathrm{cm}^{-1}\right)$.

\section{Thermal tolerance}

Upper and lower thermal limits showed significant differences among species (UTL: $F$ $=10575.54, p<0.001$; LTL: $F=84.37, p<0.001)$ but not between sexes, and both limits were significantly dependent on acclimation conductivity (UTL: $F=29014.84, p$ $<0.001$; LTL: $F=491.48, p<0.001$ ) (Table $\mathrm{S} 1.2$ ). Significant conductivity x species interactions were found for both thermal limits (UTL: $F=9249.39, p<0.001$; LTL: $F$ $=69.09, p<0.001)$. At $16 \mathrm{mS} \mathrm{cm}{ }^{-1} T . v$. verticalis presented the highest UTL $\left(51.5^{\circ} \mathrm{C} \pm\right.$ $0.05)$ with a similar value to $S$. scripta $\left(50.4{ }^{\circ} \mathrm{C} \pm 0.13\right)$, and significantly higher than $S$. selecta $\left(49.6^{\circ} \mathrm{C} \pm 0.07\right)$ and S. lateralis $\left(47.5^{\circ} \mathrm{C} \pm 0.14\right)$ (Figure 3a). However, at $37 \mathrm{mS}$ $\mathrm{cm}^{-1}$ UTL did not differ between $T$. v. verticalis and S. selecta (Figure 3a), but decreased in $T . v$. verticalis when conductivity increased. LTL for T. v. verticalis (-8.9 $\left.{ }^{\circ} \mathrm{C} \pm 0.17\right)$ was weaker than for $S$. selecta $\left(-10.8^{\circ} \mathrm{C} \pm 0.14\right)$, and similar to that of $S$.

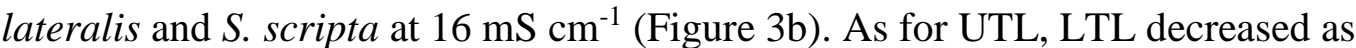
conductivity increased for both $T . v$. verticalis and S. selecta.

\section{Oviposition rates}

Oviposition rates differed significantly among species $(F=3.40, p=0.024)$ (Table S1.3). The oviposition rate of T. v. verticalis was significantly higher than that of Sigara species at $37 \mathrm{mS} \mathrm{cm}^{-1}$ (Figure 4) but not at $16 \mathrm{mS} \mathrm{cm}{ }^{-1}$. Trichocorixa v. verticalis oviposition rate increased from 1.6 eggs day ${ }^{-1}$ at $16 \mathrm{mS} \mathrm{cm}^{-1}$ to 2.2 eggs day $^{-1}$ at $37 \mathrm{mS}$ 
$\mathrm{cm}^{-1}$, in contrast to what was observed for S. selecta $\left(0.2\right.$ eggs day ${ }^{-1}$ at both conductivities). Trichocorixa $v$. verticalis females were able to lay up to 29 eggs at 16 $\mathrm{mS} \mathrm{cm}-1$ in one day, whilst the maximum number of eggs laid by a Sigara female in one day was six (for $S$. scripta and S. selecta).

\section{Wing morphology}

Differences among species (WL: $F=12.81, p<0.001$; WAR: $F=28.98, p<0.001$ ) and between sexes (WL: $F=40.52, p<0.001$; WAR: $F=6.07, p=0.015$ ) were significant for both wing loading and wing aspect ratio (Figure 5 and Table S1.4). Trichocorixa $v$. verticalis (particularly males) had the lowest wing loading values, although significant differences were only found with S. scripta which had the highest value (Figure 5a). Trichocorixa $v$. verticalis also presented the highest wing aspect ratio (Figure 5b), indicating a longer and narrower wing shape compared to the broader and more rounded wings for Sigara species (Figure 5c). Females presented significantly higher wing loading than males except for $S$. lateralis, where no differences between sexes were found. For wing aspect ratio, significant differences between sexes were only found for S. selecta, males showing a higher ratio than females.

\section{DISCUSSION}

Of the studied species, the invasive $T . v$. verticalis had higher values for traits related with establishment (i.e. the highest oviposition rate at mesosaline conditions, and highest conductivity tolerance of eggs) and spread (i.e. the highest wing aspect ratio and the lowest wing loading in males) phases of invasion. This combination of traits together with wide physiological tolerance to salinity and temperature (Table 2) may largely explain the high rates of survival and reproduction of the introduced species in 
Doñana, and the recent geographical expansion of this species (Carbonell et al., 2012a; Guareschi et al., 2015). These results are consistent with the characteristics attributed to successful invaders, considered to be species which have some combination of high dispersal ability, high reproductive output, generalist feeding, and broad environmental tolerance (Havel et al., 2015).

In subsaline and hyposaline conditions ( 0.6 and $16 \mathrm{mS} \mathrm{cm}^{-1}$, respectively), $T . v$. verticalis showed similar survival times to native species for adults and nymphs, but showed the highest tolerance to elevated temperature (at $16 \mathrm{mS} \mathrm{cm}^{-1} T . v$. verticalis presented the highest UTL). This finding is consistent with the thermal tolerance previously described for $T . v$. verticalis at different acclimation temperatures and salinities (Coccia et al. 2013). However, S. lateralis is probably the most competitive species at low conductivities, because it had a similar oviposition rate but the shortest hatching time and the highest hatching success (100\%).

In mesosaline conditions, $T$. v. verticalis may have a competitive advantage over $S$. selecta because of its higher oviposition rate, although these two species showed similar salinity tolerance and upper thermal limits at both adult and nymph stages. However, the invasive species was less tolerant to low temperature than S. selecta. According to our results, the ability of $T . v$. verticalis to deal with high and low temperatures decreases at high salinities, reducing its thermal range. Climatic models of its potential distribution (Guareschi et al., 2013) appear to support our results. These models indicate that $T . v$. verticalis prefers areas with low variability in climatic conditions, such as coastal areas, in its potential invasive distribution range. This could be due to the 
423 limited capacity of adults to withstand extreme cold in continental areas and at high altitudes (Guareschi et al., 2013).

At the highest conductivity $\left(74 \mathrm{mS} \mathrm{cm}^{-1}\right), T . v$. verticalis out-performed $S$. selecta due to higher salinity tolerance and hatching success of eggs in chloride-rich waters, despite the greater adult salinity tolerance of the native species. Previous laboratory studies (Carbonell et al., 2012b and unpublished data) found that both species showed wide tolerance to different anionic composition, although the invasive species is restricted to coastal wetlands where salts, derived from seawater, are dominated by $\mathrm{NaCl}$. The native species (S. selecta) is also capable of occupying inland waters with higher sulphate concentrations than coastal wetlands (Carbonell et al., 2012b), and is apparently more sulphate tolerant.

Many aquatic species have adaptations that allow persistence in temporary environments, such as dormant stages and spores in prokaryotes, seeds of aquatic plants or resting eggs in zooplankton (Havel et al., 2015). Therefore, production of eggs resistant to high salinities could be advantageous in temporary saline pools. In these habitats, evaporation produces a marked increase in salinity, thus the production of resistant eggs to drought and high salinity conditions is a useful strategy that permits hatching when water levels increase and salinity decreases (Williams, 2006). However, there is no evidence of drought tolerance of eggs of $T . v$ verticalis in the invaded area (unpublished data). In their native range, two other subspecies of $T$. verticalis (T. $v$. interiores and T. v. sellaris) produce diapausing eggs that allow them to survive in ice, hypersaline waters or temporary pools (Tones, 1977; Kelts, 1979). 
Resistant eggs coupled with the higher egg production observed in our study and the ability to breed throughout the year in the invaded area (Rodríguez-Pérez et al., 2009) are biological traits common in invasive species (Havel et al. 2015) that may promote the establishment and dispersal of $T . v$. verticalis in new areas and the displacement of S. selecta from mesosaline to hipersaline wetlands, as apparently observed in Morocco (L'Modhi et al., 2010). In Doñana wetlands, the invasive species attains the highest population densities in waters of intermediate conductivities of $17-55 \mathrm{mS} \mathrm{cm}^{-1}$ (Rodríguez-Pérez et al., 2009), overlapping with the conductivity range of S. selecta, except in extreme salinities where $T$. $v$. verticalis could be excluded by the lower salinity tolerance of the adult stage. However, the lower part of the T. v. verticalis salinity niche overlaps with the upper part of the S. scripta and S. lateralis niches, where these native species could be less competitive.

Although the distribution of $T . v$. verticalis in the invaded area can be explained largely by its wide physiological tolerance to salinity, biological interactions with native hemiptera and other macroinvertebrates (competition, predation or even parasitism) may also be important determinants of its abundance in specific habitats, as in other corixid species (Scudder, 1983). The predation rate on T. verticalis by Odonata larvae was higher than that of S. lateralis, probably because of the smaller size of the alien (Coccia et al., 2014). This might help to explain the rarity of $T . v$. verticalis in Doñana wetlands of lower conductivity, where Odonata larvae are abundant. In addition, $T$. v. verticalis showed higher parasitism by the water mites Hydrachna skorikowi and Eylais infundibulifera than S. lateralis and S. scripta in low salinity Doñana wetlands (Sánchez et al. 2015). Thus, T. v. verticalis is under higher parasitic and predation pressure than native Sigara species at low salinities, which may help to explain why T. v. verticalis is 
particularly successful in saline habitats where parasitic mites and Odonata larvae are absent.

The survival of invasive species under harsh environmental conditions or biological interactions is only half of the invasion story. Resting stages and/or adults must also move from one habitat to others. With the exception of flying insects and mobile vertebrates, most aquatic species lack the means for active dispersal into isolated hydrological catchments and instead use a variety of transport vectors for passive dispersal, such as transport by wind or vertebrates such as birds (Havel \& Shurin, 2004). In the case of $T . v$. verticalis, its rapid spread to nearby wetlands may be promoted by its high capacity for active and passive dispersal. Trichocorixa v. verticalis presents the lowest wing loading of males, related to superior flying ability (Berwaerts et al., 2002) and the highest wing aspect ratio, related with fast-flapping and energy efficient active flight (Hoffsten, 2004). Thus, wing morphometrics suggest that T. v. verticalis may be a stronger flier than native species, which would facilitate its ability to move between water bodies to breed or to avoid unfavorable environmental conditions, especially when temporary habitats dry out. In general, corixids disperse actively to suitable aquatic habitats mainly between early spring, when individuals fly to new potential breeding areas, and late fall when the population density peaks and habitats begin to dry out (Pajunen \& Jansson, 1969; Boda \& Csabai, 2009). The most suitable periods for dispersal are dawn and late evening hours, which are usually free of wind and rain, with a higher relative air humidity and lower air temperature (Boda \& Csabai, 2009). Besides, males of all the studied species, except $S$. lateralis, show greater flight ability than females so as to actively move among water bodies, probably to search for females. In general, corixid females, larger than males, invest more in reproduction and less in dispersal (i.e. oogenesis flight syndrome) when environmental conditions are favorable, 
owing to a trade-off between the high energy costs of egg production and of flight (Velasco et al., 1990). In contrast, males invest more energy in developing flight muscles to actively search for females.

In conclusion, the establishment and spread success of the alien $T$. v. verticalis could be principally due to its high egg production, high resistance to salinity, heat and harsh environmental conditions, and its better flight ability. Further studies of other biological traits, such as voltinism, development rate, diet and body size differences should contribute to define its functional and ecological niche and a better understanding of the establishment success and impact of the species in the invaded area.

\section{ACKNOWLEDGMENTS}

We thank Raquel López, Susana Pallarés, Simone Guareschi, Cayetano GutiérrezCánovas and Félix Picazo for field and laboratory assistance; Paula Arribas, David Sánchez-Fernández, Pedro Abellán and David Bilton for their help and suggestions; José Galián for technical support and the members of the Aquatic Ecology research group (Universidad de Murcia, Spain) and the Wetlands Ecology department (EBD CSIC, Seville, Spain) for their help at various stages of this project. This work was partially supported by funding from a predoctoral FPU grant to J.A. Carbonell, a JAE predoctoral grant to C. Coccia, an $11^{\circ}$ Arquímedes young investigators award to V. Céspedes and projects P10-RNM-6262 (Consejería de Innovación, Ciencia y empresa, Junta de Andalucía), “Atlas de los coleópteros acuáticos de España peninsular” (A.M.) (Ministerio de Agricultura, Alimentación y Medio Ambiente) and CGL2010-15378 (J.V.) cofinanced by FEDER funds. 


\section{REFERENCES}

Alonso, A. \& J. A. Camargo, 2003. Short-term toxicity of ammonia, nitrite and nitrate to the aquatic snail Potamopyrgus antipodarum (Hidrobiidae, Mollusca). Bulletin of Environmental Contamination and Toxicology 70: 1006-1012.

Alonso, A. \& J. A. Camargo, 2004. Sub-lethal responses of the aquatic snail Potamopyrgus antipodarum (Hydrobiidae, Mollusca) to unionised ammonia: a tolerant invading species. Fresenius Environmental Bulletin 13: 607-615. Arribas, P., Velasco, J., Abellán, P., Sánchez-Fernández, D., Andújar, C., Calosi, P., Millán, A., Ribera, I. \& D. Bilton, 2012. Dispersal ability rather than ecological tolerance drives differences in range size between lentic and lotic water beetles (Coleoptera: Hydrophilidae). Journal of Biogeography 39: 984-994. Aukema, B. \& C. Rieger, 1995. Catalogue of the Heteroptera of the Paleartic Region. Vol. 1: Enicocephalomorpha, Dipsocoromorpha, Nepomorpha, Gerromorpha and Leptopodomorpha. Netherlands Entomological Society. Amsterdam.

Berwaerts, K., Van Dyck, H. \& P. Aerts, 2002. Does flight morphology relate to flight performance? An experimental test with the butterfly Pararge aegeria. Functional Ecology 16: 484-491.

Blackburn, T. M., Pyšek, P., Bacher, S., Carlton, J. T., Duncan, R. P., Jarošík, V., Wilson, J. R. U. \& D. M. Richardson, 2011. A proposed unified framework for biological invasions. Trends in Ecology and Evolution 26: 333-339. Boda, P. \& Z. Csabai, 2009. Seasonal and diel dispersal activity characteristics of Sigara lateralis (Leach, 1817) (Heteroptera: Corixidae) with special emphasis on possible environmental factors and breeding state. Aquatic Insects 31: 301-314. Calosi, P., Bilton, D. T. \& J. I. Spicer, 2008. Thermal tolerance, acclimatory capacity and vulnerability to global climate change. Biology Letters 4: 99-102. 
Carbonell, J. A., Guareschi, S., Coccia, C., Sánchez-Fernández, D., Velasco, J., Boyero, L., Green, A. J. \& A. Millán, 2012a. Distribución de Trichocorixa verticalis verticalis (Fieber, 1851) (Heteroptera: Corixidae) a nivel mundial y su expansión en la Península

\section{Notas Científicas. pp. 148-152. $4^{\circ}$ Congreso Nacional sobre Especies Exóticas} Invasoras “EEI 2012”. GEIB, Serie Técnica N 5. León, 218 pp.

Carbonell, J. A., Gutiérrez-Cánovas, C., Bruno, D., Abellán, P., Velasco, J. \& A. Millán, 2011. Ecological factors determining the distribution and assemblages of the aquatic hemiptera (Gerromorpha \& Nepomorpha) in the Segura river basin (Spain). Limnetica 30: 59-70.

Carbonell, J. A., Millán, A. \& J. Velasco, 2012b. Concordance between realised and fundamental niches in three Iberian Sigara species (Hemiptera: Corixidae) along a gradient of salinity and anionic composition. Freshwater biology 57: 2580-2590.

Castro-Longoria, E. 2003. Egg production and hatching success of four Acartia species under different temperature and salinity regimes. Journal of Crustacean Biology 23: 289-299.

Chown S. L. \& W. N. Nicolson, 2004. Insect Physiological Ecology: Mechanisms and Patterns. Oxford University Press, U.K.

Chown, S. L. \& J. S. Terblanche, 2007. Physiological diversity in insects: ecological and evolutionary contexts. Advances in Insect Physiology 33: 50-152.

Coccia, C., Boyero, L. \& A. J. Green, 2014. Can differential predation of native and alien corixids explain the success of Trichocorixa verticalis verticalis in the Iberian Peninsula? Hydrobiologia 734: 115-123.

Coccia, C., Calosi, P., Boyero, L., Green, A. J. \& D. T. Bilton, 2013. Does

Ecophysiology Determine Invasion Success? A Comparison between the Invasive 
Boatman Trichocorixa verticalis verticalis and the Native Sigara lateralis (Hemiptera,

Corixidae) in South-West Spain. PLoS ONE, 8(5): e63105.

doi:10.1371/journal.pone.0063105.

Dolédec, S., Chessel, D. \& C. Gimaret-Carpentier, 2000. Niche separation in community analysis: a new method. Ecology 81: 2914-2927.

Dudgeon, D., Arthington, A. H., Gessner, M. O., Kawabata, Z., Knowler, D. J., Lévêque, C., Naiman, R. J., Prieur-Richard, A. H., Soto, D., Stiassny, M. L. J. \& C. A. Sullivan, 2006. Freshwater biodiversity: Importance, threats, status and conservation challenges. Biological reviews of the Cambridge Philosophical Society 81: 163-182. Espinar, J. L., Díaz-Delgado, R., Bravo-Utrera, M. A. \& M. Vilà, 2015. Linking Azolla filiculoides invasion to increased winter temperatures in the Doñana marshland (SW Spain). Aquatic Invasions 10. doi: http://dx.doi.org/10.3391/ai.2015.10.1.02 Figuerola, J., Green, A. J. \& L. Santamaria, 2003. Passive internal transport of aquatic organisms by waterfowl in Doñana, south-west Spain. Global Ecology and Biogeography 12: 427-436.

Gelin, A., Crivelli, A. J., Rosecchi, E. \& P. Kerambrun, 2001. Can salinity changes affect reproductive success in the brown shrimp Crangon crangon? Journal of Crustacean Biology 21: 905-911.

Gérard, C., Blanc, A. \& K. Costil, 2003. Potamopyrgus antipodarum (Mollusca:Hydrobiidae) in continental aquatic gastropod communities: impact of salinity and trematode parasitism. Hydrobiologia 493: 167-172.

Gibb, H., Hjalten, J., Ball, J. P., Pettersson, R. B., Landin, J., Alvini, O. \& K. Danell, 2006. Wing loading and habitat selection in forest beetles: are red-listed species poorer dispersers or more habitat-specific than common congenerics? Biological Conservation 132: $250-260$. 
Guareschi, S., Abellán, P., Laini, A., Green, A. J., Sánchez-Zapata, J. A., Velasco, J. \&

600

601

A. Millán, 2015. Cross-taxon congruence in wetlands: Assessing the value of waterbirds as surrogates of macroinvertebrate biodiversity in Mediterranean Ramsar sites. Ecological Indicators 49: 204-215.

Guareschi, S., Coccia, C., Sánchez-Fernández, D., Carbonell, J. A., Velasco, J., Boyero, L., Green, A. J. \& A. Millán, 2013. How Far Could the Alien Boatman Trichocorixa verticalis verticalis Spread? Worldwide Estimation of Its Current and Future Potential Distribution. PLoS ONE 8(3): e59757. doi:10.1371/journal.pone.0059757.

Günther, H. 2004. Trichocorixa verticalis verticalis (Fieber), eine nearktische Ruderwanze in Europa (Heteroptera: Corixidae). Mitteilungen des Internationalen Entomologischen Verereins 29: 45-49.

Havel, J.E., Kovalenko, K.E., Thomaz, S.M., Amalfitano, S. \& L. B. Kats, 2015. Aquatic invasive species: challenges for the future. Hydrobiologia 750: 147-170. Havel, J. E. \& J. B. Shurin, 2004. Mechanisms, effects, and scales of dispersal in freshwater zooplankton. Limnology and Oceanography 49: 1229-1238. Hoffsten, P. 2004. Site-occcupancy in relation to flight-morphology in caddisflies. Freshwater Biology 49: 810-817.

Hutchinson, G. E. 1931. On the occurrence of Trichocorixa kirkaldy (Corixidae, Hemiptera-Heteroptera) in salt water and its zoo-geo-graphical significance. American Naturalist 65: 573-5749. Jansson, A. 2002. New records of Corixidae (Heteroptera) from northeastern USA and eastern Canada, with one new synonymy. Entomologica Fennica 13: 85-88.

Kelts, L. J. 1979. Ecology of a tidal marsh corixid, Trichocorixa verticalis (Insecta, Hemiptera). Hydrobiologia 64: 37-57. 
L’Mohdi, O., Bennas, N., Himmi, O., Hajji, K., El Haissoufi, M., Hernando, C., Carbonell, J. A. \& A. Millán, 2010. Trichocorixa verticalis verticalis (Fieber 1851)

(Hemiptera, Corixidae): une nouvelle especie exotique au Maroc. Boletín de la Sociedad Entomológica Aragonesa 46: 395-400.

Macan, T. T. 1976. A revised key to the British Water Bugs (Hemiptera-Heteroptera) with notes on their Ecology. Freshwater Biological Association Scientific Publication, 16, Ambleside: Freshwater Biological Association, 77p.

Martínez, I. 2002. Técnicas básicas de anatomía microscópica y de morfometría para estudiar los insectos. Boletín de la Sociedad Entomológica Aragonesa 30: 187-195. Millán, A., Hernándo, C., Aguilera, P., Castro, A. \& I. Ribera, 2005. Los coleópteros acuáticos y semiacuáticos de Doñana: Reconocimiento de su biodiversidad y prioridades de conservación. Boletín de la Sociedad Entomológica Aragonesa 36: 157164.

Millán, A., Velasco, J., Nieser, N. \& C. Montes, 1988. Heterópteros acuáticos (Gerromorpha \& Nepomorpha) de la Cuenca del Río Segura. S.E. de la Península Ibérica. Anales de Biología 11: 71-80.

Moreno, J. L., Millán, A., Suarez, M. L., Vidal-Abarca, R. \& J. Velasco, 1997. Aquatic Coleoptera and Heteroptera assemblages in waterbodies from ephemeral coastal streams ("ramblas") of south-eastern Spain. Archiv für Hydrobiologie 141: 93-107.

Nieser, N., Baena, M., Martínez-Avilés, J. \& A. Millán, 1994. Claves para la identificación de los heterópteros acuáticos (nepomorpha \& gerromorpha) de la Península Ibérica -Con notas sobre las especies de las Islas Azores, Baleares, Canarias y Madeira. Asociación Española de Limnología. Madrid. 
Pajunen, V. I. \& A. Jansson, 1969. Dispersal of the rock pool corixids Arctocorixa carinata (Sahlb.) and Callicorixa producta (Reut.) (Heteroptera, Corixidae). Annales Zoologici Fennici 6: 391-427.

Parker, I. M., Simberloff, D., Lonsdale, W. M., Goodell, K., Wonham, M., Kareiva, P.

M., Williamson, M. H., Von Holle, B., Moyle, P. B., Byers, J. E. \& L. Goldwasser, 1999. Impact: toward a framework for understanding the ecological effects of invaders. Biological Invasions 1: 3-9.

Popham, E. J. 1964. The migration of aquatic bugs with special reference to the Corixidae (Hemiptera Heteroptera). Archiv für Hydrobiologie 60: 450-496.

Rabitsch, W. 2008. Alien true bugs of Europe (Insecta: Hemiptera: Heteroptera). Zootaxa 1827: 1-44.

Quinn, G. \& Keough, 2002. Experimental Design and Data Analysis for Biologists. Cambridge University Press. Cambridge. 537 pp.

R Core Team. 2014. R: A language and environment for statistical computing. $\mathrm{R}$ Foundation for Statistical Computing, Vienna, Austria. ISBN 3-900051-07-0, URL http://www.R-project.org.

Ricciardi, A. 2006. Are modern biological invasions an unprecendent form of global change? Conservation Biology 21: 329-336.

Richards, D. C. 2002. The New Zealand mudsnail invades the Western United States. Aquatic Nuisance Species 4: 42-44.

Rodríguez-Pérez, H., Florencio, M., Gómez-Rodríguez, C., Green, A.J., Día-Paniagua, C. \& L. Serrano, 2009. Monitoring the invasion of the aquatic bug Trichocorixa verticalis verticalis (Hemiptera: Corixidae) in the wetlands of Doñana National Park (SW Spain). Hydrobiologia 634: 209-217. 
Rodríguez-Pérez, H. \& A. J. Green, 2012. Strong seasonal effects of waterbirds on benthic communities in shallow lakes. Freshwater Science 31: 1273-1288.

Sakai, A. K., Allendorf, F. W., Holt, J. S., Lodge, D. M., Molofsky, J., With, K. A., Baughman, S., Cabin, R. J., Cohen, J. E., Ellstrand, N. C., McCauley, D. E., O'Neil, P., Parker, I. M., Thompson, J. N. \& S. G. Weller, 2001. The population biology of invasive species. Annual Review of Ecology and Systematics 32: 305-332.

Sala, J. \& D. Boix, 2005. Presence of the nearctic water boatman Trichocorixa verticalis verticalis (Fieber, 1951) (Heteroptera, Corixidae) in the Algarve region (S Portugal). Graellsia 61: 31-36.

Sánchez-Fernández, D., Calosi, P., Atfield, A., Arribas, P., Velasco, J., Spice,r J. I., Millán, A. \& D. T. Bilton, 2010. Reduced salinities compromise the thermal tolerance of hypersaline specialist diving beetles. Physiological Entomology 35: 265-273.

Sánchez, M., Coccia, C., Valdecasas, A. G., Boyero, L. \& A. J. Green, 2015. Parasitism by water mites in native and exotic Corixidae: Are mites limiting the invasion of the water boatman Trichocorixa verticalis (Fieber, 1851)? Journal of Insect Conservation. Doi: 10.1007/s10841-015-9764-7

Scudder, G. G. E. 1983. A review of factors governing the distribution of two closely related corixids in the saline lakes of British Columbia. Hydrobiologia 105: 143-154. Simonis, J. L. 2013. Predator ontogeny determines trophic cascade strength in freshwater rock pools. Ecosphere 4: 1-25.

Thioulouse, J., Chessel, D., Dolédec, S. \& J. M. Olivier, 1997. ADE-4: a multivariate analysis and graphical display software. Statistics and Computing 7: 75-83. Tones, P. I., 1977. Life-cycle of Trichocorixa verticalis interiores Sailer (Hemiptera: Corixidae) with special reference to diapause. Freshwater Biology 7: 31-36. 
694 Van de Meutter, F., Trekels, H. \& A. Green, 2010a. The impact of the North American waterbug Trichocorixa verticalis (Fieber) on aquatic macroinvertebrate communities in southern Europe. Fundamental and Applied Limnology 177: 283-292.

Van de Meutter, F., Trekels, H., Green, A. \& R. Stoks, 2010b. Is salinity tolerance the key to success for the invasive water bug Trichocorixa verticalis? Hydrobiologia 649: 231-238.

Velasco, J., Millán, A. \& N. Nieser, 1990. Observaciones sobre la colonización y el ciclo de vida de Heliocorisa vermiculata (puton, 1874) (Heteroptera, Corixidae) en pequeños estanques del se español. Limnetica 6: 101-108.

Weigelhofer G., Weissmair, W., \& J. Waringer, 1992. Night migration activity and the influence of meteorological parameters on light-trapping for aquatic Heteroptera. Zoologischer Anzeiger 229: 209-218.

Williams, D. D., 2006. The biology of temporary waters. Oxford, Biology, 337 pp. Wilson, P. W., Heneghan, A. F. \& A. D. J. Haymet, 2003. Ice nucleation in nature: supercooling point (SCP) measurements and the role of heterogeneous nucleation. Cryobiology 46: 88-98. 
FIGURE LEGENDS

Fig. 1. Realised niche breadths of four study species in relation to conductivity for a) adults and b) nymphs. X-axis represents the range of conductivity in the study area. conductivity of sampling sites.

Fig. 2. Mean \pm SE survival time of adults, nymphs and eggs in conductivity treatments. According to post hoc analysis with Bonferroni correction, different numbers above bars indicate significant differences $(p \leq 0.05)$ in survival time among species in a given conductivity treatment, whereas different letters above bars indicate significant differences in survival time among conductivity treatments for a given species.

Fig. 3. Mean \pm SE a) upper thermal limits and b) lower thermal limits in conductivity treatments. According to post hoc analysis with Bonferroni correction, different numbers above bars indicate significant differences $(p \leq 0.05)$ among species in a given conductivity treatment, whereas different letters above bars indicate significant differences among conductivity treatments for a given species. Experiments were not carried out on S. lateralis and S. scripta at $37 \mathrm{mS} \mathrm{cm}^{-1}$.

Fig. 4. Mean \pm SE oviposition rate of species in conductivity treatments. According to post hoc analysis with Bonferroni correction, different numbers above bars indicate significant differences $(p \leq 0.05)$ among species in a given conductivity treatment. Experiments were not carried out on S. lateralis and S. scripta at $37 \mathrm{mS} \mathrm{cm}^{-1}$. 
740 Fig. 5. Wing characteristics of the studied species: (a) wing loading, (b) wing aspect

741 ratio and (c) examples of wings of the four species. Data points represent mean values \pm

742 SE for each species (black circles, males; white circles, females). According to post hoc

743 analysis with Bonferroni correction, different numbers indicate significant differences

$744(p \leq 0.05)$ among species, whereas different letters indicate significant differences

745 among sexes for a given species.

746 

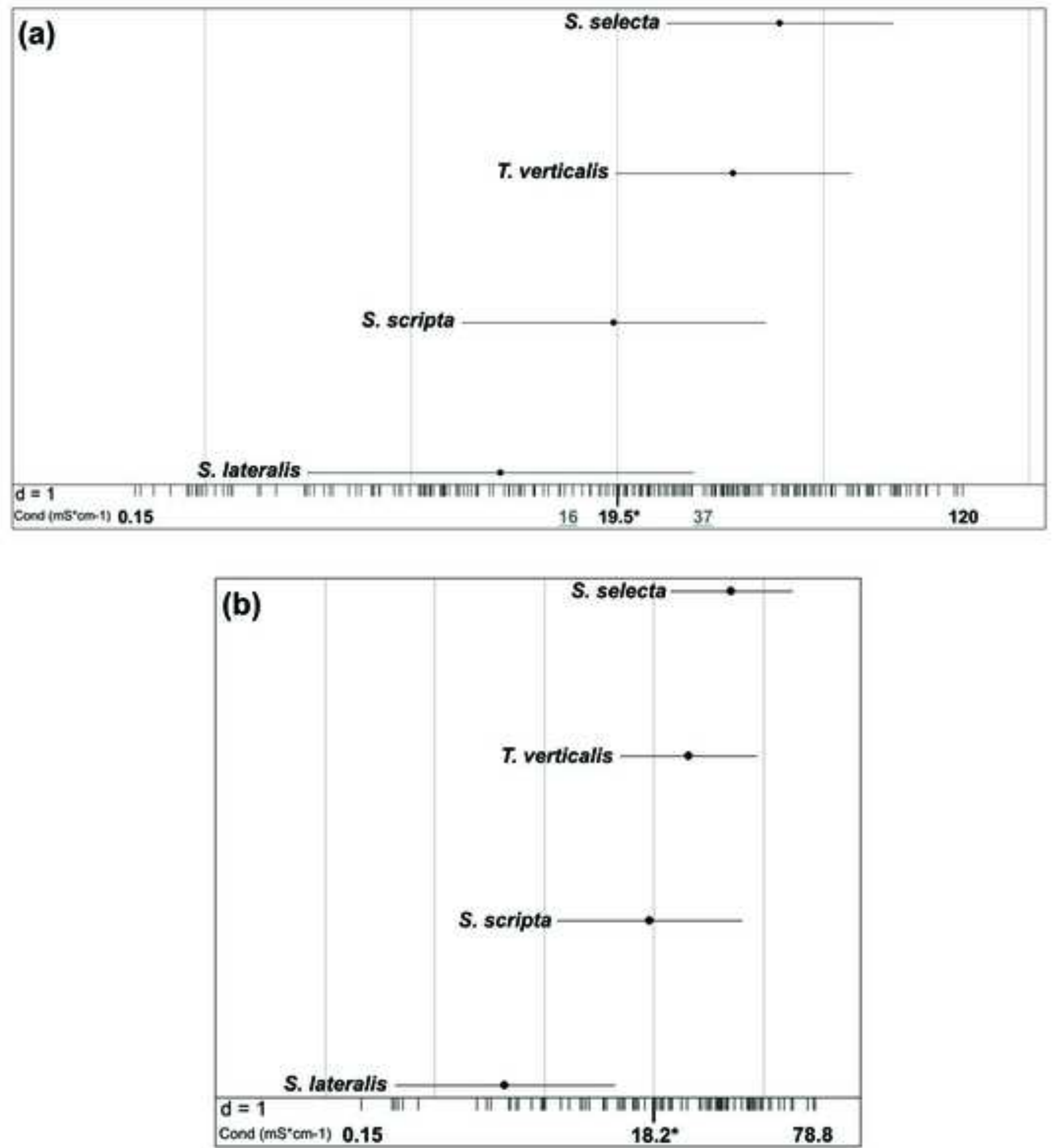

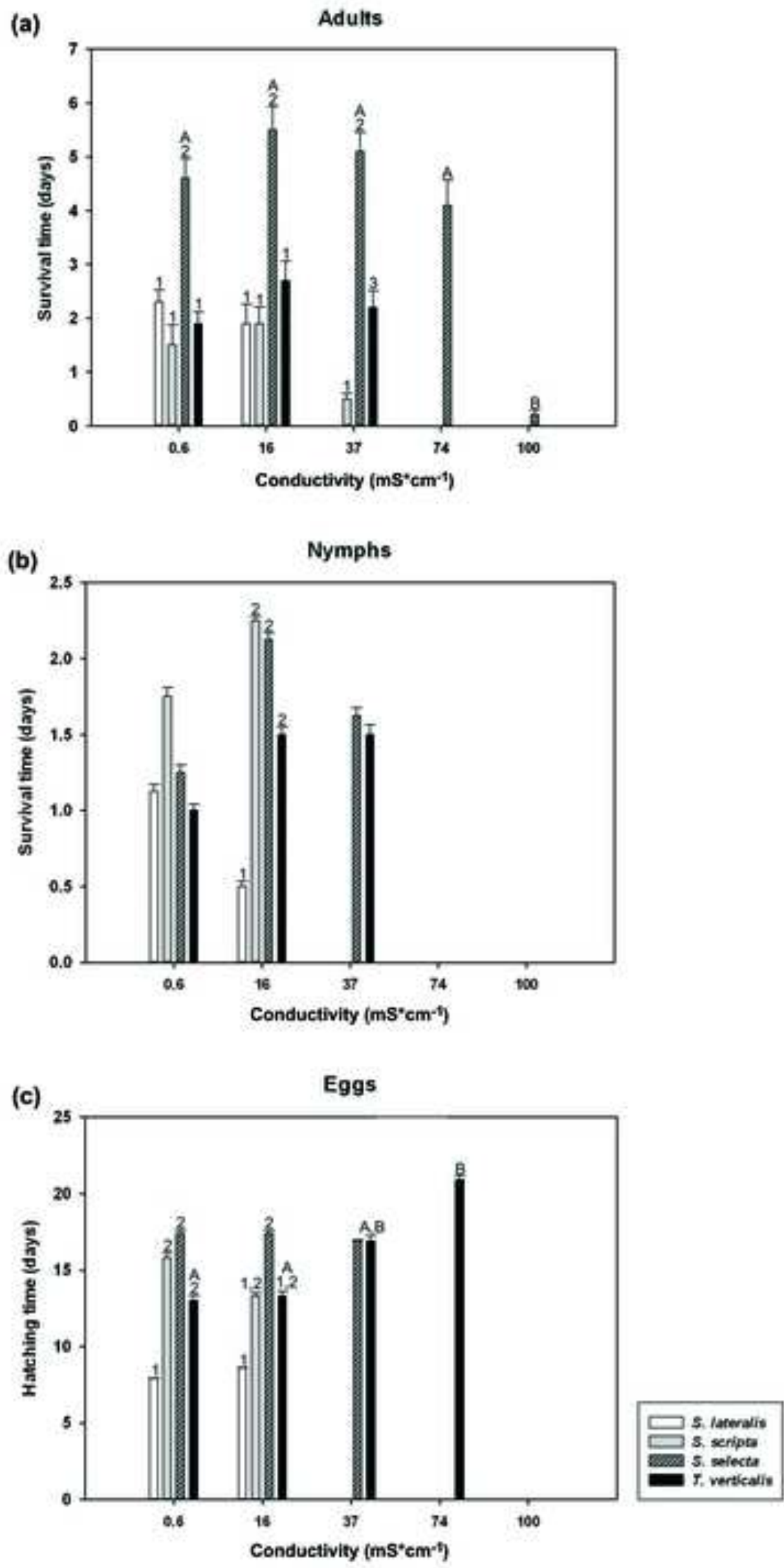


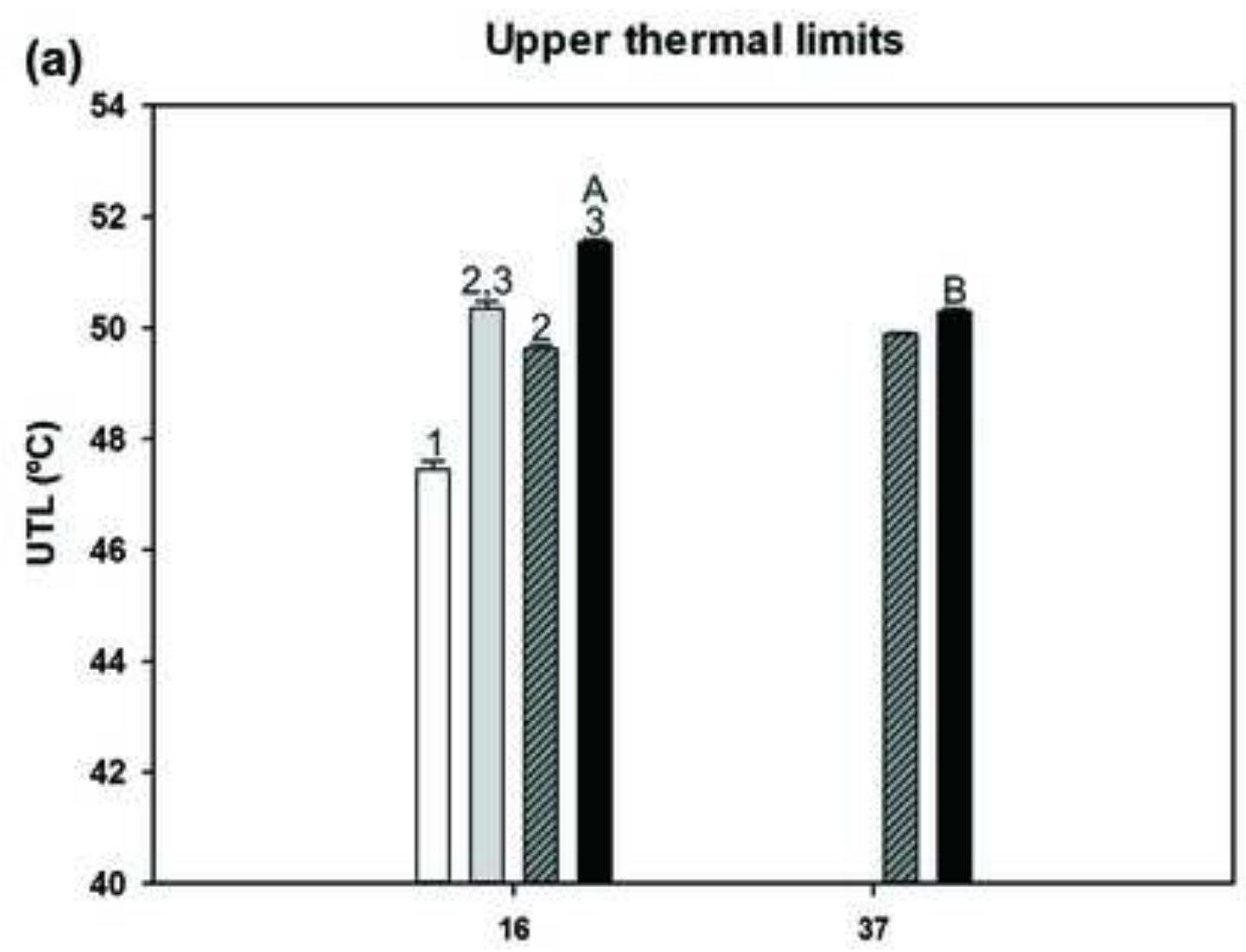

Conductivity $\left(\mathrm{mS}^{*} \mathrm{~cm}^{-1}\right)$

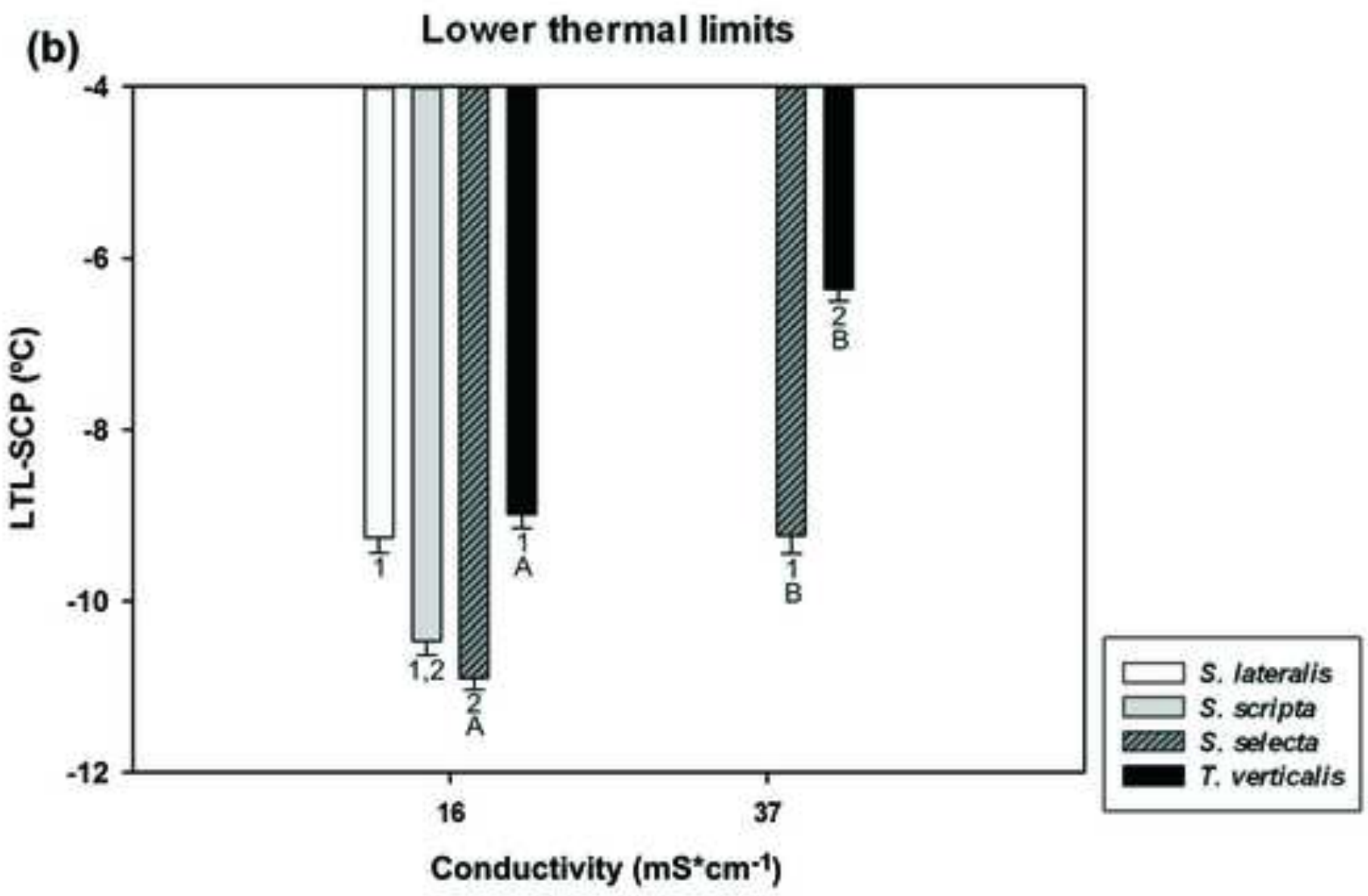




\section{Fecundity}

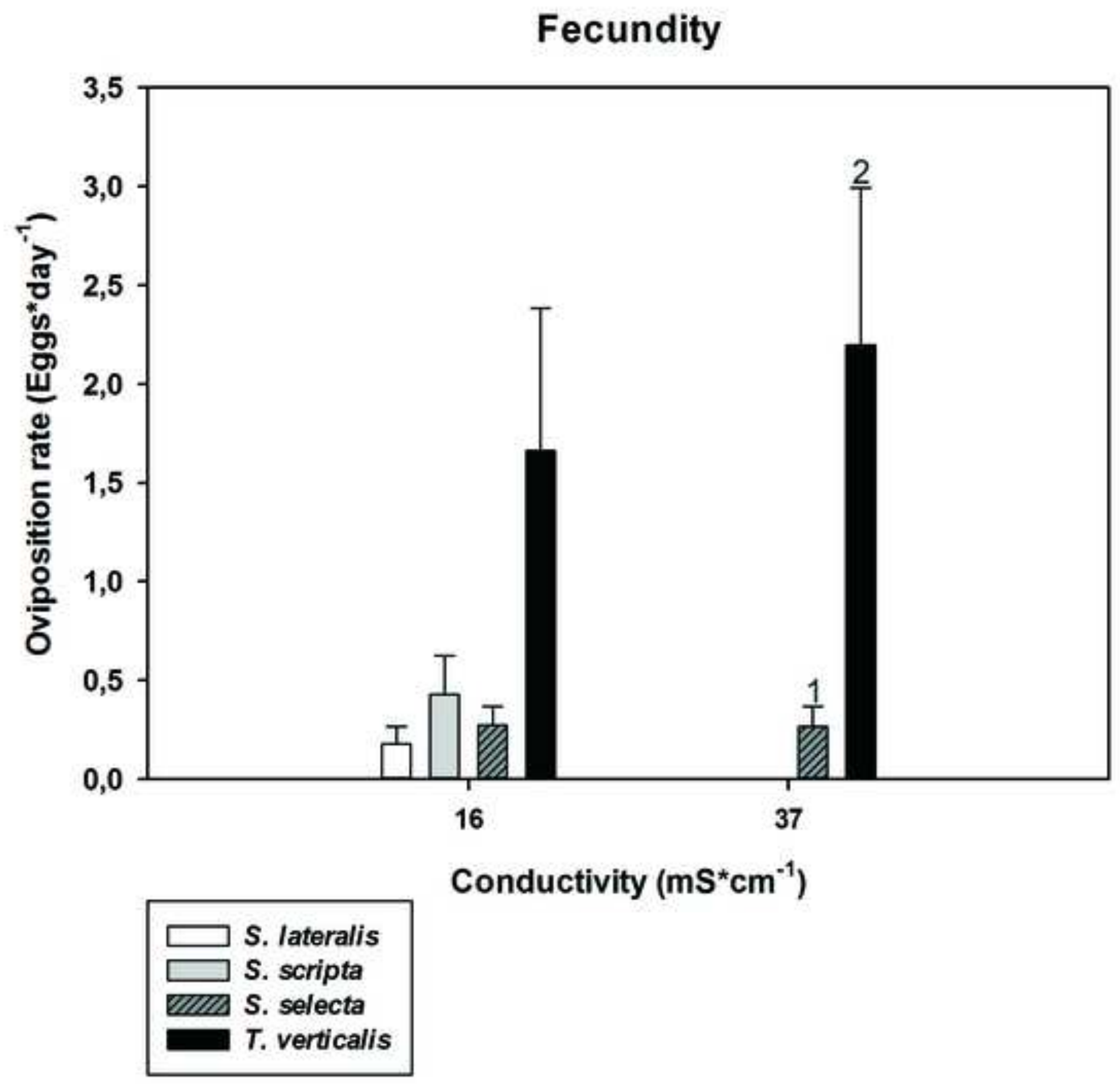




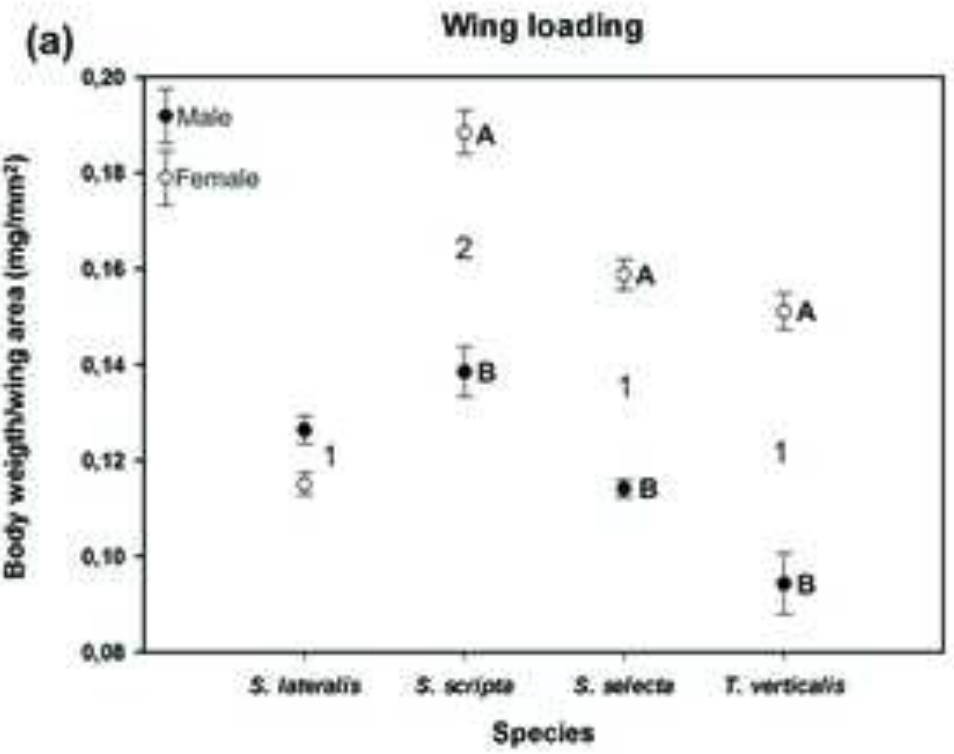

(b)

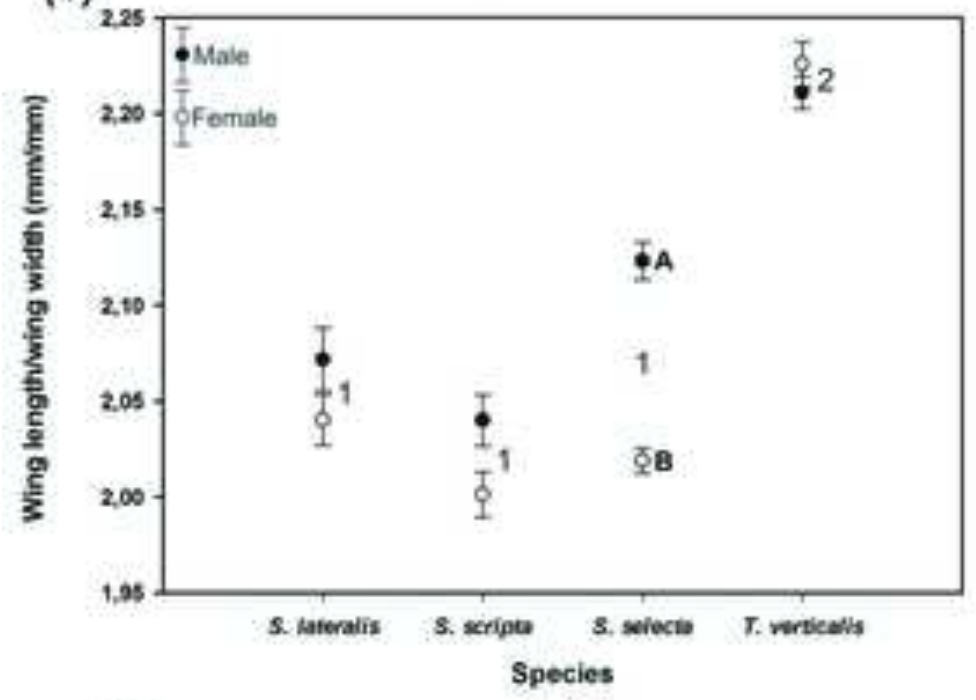

(c)

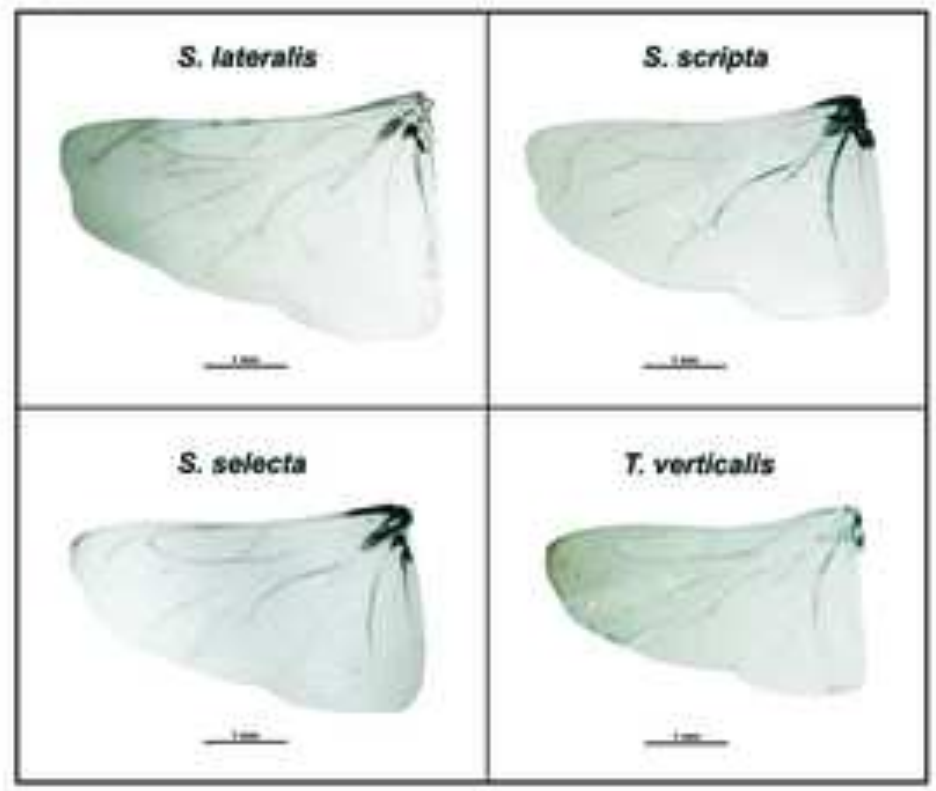




\section{TABLES}

Table 1. Collection site information (dates of collection, geographical coordinates and mean conductivity).

\begin{tabular}{|c|c|c|c|c|c|c|}
\hline Species & Sample location & Date & Latitude & Longitude & Altitude (m) & Conductivity (mS/cm) \\
\hline S. lateralis & FAO, Doñana National Park, Sevilla & spring (2013) & $37^{\circ} 04^{\prime} \mathrm{N}$ & $6^{\circ} 22^{\prime} \mathrm{O}$ & 2 & 2.08 \\
\hline S. lateralis & Charca de Las Moreras, Mazarrón, Murcia & autumn (2013) & $37^{\circ} 34^{\prime} \mathrm{N}$ & $1^{\circ} 17^{\prime} \mathrm{W}$ & 10 & 0.55 \\
\hline S. scripta & Chícamo stream, Abanilla, Murcia & spring (2011) & $38^{\circ} 11^{\prime} \mathrm{N}$ & $1^{\circ} 03^{\top} \mathrm{W}$ & 150 & 21.9 \\
\hline S. scripta & Chícamo stream, Abanilla, Murcia & autumn (2013) & $38^{\circ} 11^{\prime} \mathrm{N}$ & $1^{\circ} 03^{\top} \mathrm{W}$ & 150 & 22.2 \\
\hline S. selecta & Barranco del Diablo, Molina de Segura, Murcia & spring (2011) & $38^{\circ} 07^{\prime} \mathrm{N}$ & $1^{\circ} 08^{\prime} \mathrm{W}$ & 140 & 48.3 \\
\hline S. selecta & Barranco del Diablo, Molina de Segura, Murcia & autumn (2013) & $38^{\circ} 07^{\prime} \mathrm{N}$ & $1^{\circ} 08^{\prime} \mathrm{W}$ & 140 & 53.7 \\
\hline T.v. verticalis & Veta la Palma, Doñana Natural Park, Sevilla & spring \& autumn (2013) & $36^{\circ} 54^{\prime} \mathrm{N}$ & $6^{\circ} 15^{\prime} \mathrm{O}$ & 1 & 33.7 \\
\hline
\end{tabular}

Table 2. Summary of the studied traits expressed as average \pm SE, except for salinity tolerance expressed as $\mathrm{LC}_{50}(95 \%$ confidence interval). $*$ traits at which $T$. v. verticalis outperformed the other species.

\begin{tabular}{|c|c|c|c|c|c|c|}
\hline & \\
\hline & & $\mathbf{N}$ & S. lateralis & S. scripta & S. selecta & T. verticalis \\
\hline \multirow{3}{*}{\multicolumn{2}{|c|}{$\begin{array}{l}\text { Sal. Tol. }\left(\mathrm{LC}_{50}-48 \mathrm{~h}\right) \text { adults } \\
\text { Sal. Tol. }\left(\mathrm{LC}_{50}-48 \mathrm{~h}\right) \text { nymphs } \\
\text { Sal. Tol. }\left(\mathrm{LC}_{50}-25 \mathrm{~d}\right) \text { eggs }\end{array}$}} & 50 & $12.85(5.27-31.30)$ & 17.18 & $78.65(67.01-92.31)$ & $43.41(33.81-55.74)$ \\
\hline & & 50 & 1.36 & 23.35 & $35.58(12.75-99.29)$ & $46.13 *$ \\
\hline & & 50 & 52.33 & 24.33 & 24.33 & $55.40(42.63-72.00)^{*}$ \\
\hline \multirow{2}{*}{$\begin{array}{l}\text { Fecundity } \\
\text { (eggs/day) }\end{array}$} & $16 \mathrm{mS} / \mathrm{cm}$ & 10 & $0.17 \pm 0.07$ & $0.55 \pm 0.18$ & $0.66 \pm 0.09$ & $1.20 \pm 0.43$ \\
\hline & 37 mS/cm & 10 & - & - & $0.41 \pm 0.07$ & $6.06 \pm 2.04 *$ \\
\hline \multirow{4}{*}{$\begin{array}{l}\text { Hatching time } \\
\text { (days) }\end{array}$} & $0.6 \mathrm{mS} / \mathrm{cm}$ & 10 & $7.90 \pm 0.04$ & $15.80 \pm 0.32$ & $17.40 \pm 0.21$ & $13.00 \pm 0.32$ \\
\hline & 16 mS/cm & 10 & $8.60 \pm 0.03$ & $13.30 \pm 0.21$ & $17.40 \pm 0.20$ & $13.30 \pm 0.31$ \\
\hline & 37 mS/cm & 10 & 0 & 0 & $16.90 \pm 0.05$ & $16.90 \pm 0.35$ \\
\hline & $74 \mathrm{mS} / \mathrm{cm}$ & 10 & 0 & 0 & 0 & $20.90 \pm 0.27 *$ \\
\hline \multirow{4}{*}{$\begin{array}{l}\text { Hatching success } \\
(\%)\end{array}$} & $0.6 \mathrm{mS} / \mathrm{cm}$ & 10 & 100 & 70 & 80 & 80 \\
\hline & 16 mS/cm & 10 & 100 & 90 & 80 & 80 \\
\hline & 37 mS/cm & 10 & 0 & 0 & 100 & 60 \\
\hline & $74 \mathrm{mS} / \mathrm{cm}$ & 10 & 0 & 0 & 0 & $40 *$ \\
\hline \multirow{2}{*}{ UTL-HC $\left({ }^{\circ} \mathrm{C}\right)$} & 16 mS/cm & 40 & $47.46 \pm 0.14$ & $50.36 \pm 0.13$ & $49.63 \pm 0.07$ & $51.54 \pm 0.06^{*}$ \\
\hline & 37 mS/cm & 40 & - & - & $49.89 \pm 0.03$ & $50.30 \pm 0.06^{*}$ \\
\hline \multirow{2}{*}{ LTL-SCP $\left({ }^{\circ} \mathrm{C}\right)$} & 16 mS/cm & 40 & $-9.25 \pm 0.18$ & $-10.47 \pm 0.16$ & $-10.90 \pm 0.14$ & $-8.98 \pm 0.17$ \\
\hline & $37 \mathrm{mS} / \mathrm{cm}$ & 40 & - & - & $-9.23 \pm 0.21$ & $-6.36 \pm 0.14$ \\
\hline \multicolumn{2}{|c|}{ Wing loading $\left(\mathrm{mg} / \mathrm{mm}^{2}\right)$} & 40 & $0.11 \pm 0.00$ & $0.15 \pm 0.03$ & $0.13 \pm 0.00$ & $0.11 \pm 0.00$ \\
\hline \multicolumn{2}{|c|}{ Wing aspect ratio $(\mathrm{mm} / \mathrm{mm})$} & 40 & $2.06 \pm 0.01$ & $2.02 \pm 0.01$ & $2.07 \pm 0.01$ & $2.22 \pm 0.01 *$ \\
\hline
\end{tabular}




\section{SUPPORTING INFORMATION}

What traits underpin the establishment and spread success of the invasive water bug

Trichocorixa verticalis verticalis?

J.A. Carbonell, A. Millán, A.J. Green, V. Céspedes, C. Coccia \& J. Velasco

Hydrobiologia

Appendix S1 Analysis results

S1.1. Significant differences (Kruskal-Wallis test) among species and conductivities for survival times of adults and nymphs, and hatching time of eggs.

\begin{tabular}{|c|c|c|c|c|c|}
\hline \multicolumn{6}{|c|}{ Species } \\
\hline Phase & Species & $\mathbf{N}$ & Mean rank & Chi-square & p-value \\
\hline \multirow[t]{5}{*}{ Adults } & S. lateralis & 50 & 78.12 & 53.49 & $<0.001$ \\
\hline & S. scripta & 50 & 78.92 & & \\
\hline & S. selecta & 50 & 147.13 & & \\
\hline & T. v. verticalis & 50 & 97.83 & & \\
\hline & Total & 200 & & & \\
\hline \multirow[t]{5}{*}{ Nymphs } & S. lateralis & 50 & 82.62 & 10.18 & 0.017 \\
\hline & S. scripta & 50 & 101.47 & & \\
\hline & S. selecta & 50 & 113.12 & & \\
\hline & T. v. verticalis & 50 & 104.79 & & \\
\hline & Total & 200 & & & \\
\hline \multirow[t]{5}{*}{ Eggs } & S. lateralis & 50 & 67.50 & 39.93 & $<0.001$ \\
\hline & S. scripta & 50 & 86.67 & & \\
\hline & S. selecta & 50 & 118.99 & & \\
\hline & T. v. verticalis & 50 & 128.84 & & \\
\hline & Total & 200 & & & \\
\hline
\end{tabular}

\begin{tabular}{|c|c|c|c|c|c|}
\hline \multicolumn{6}{|c|}{ Conductivity } \\
\hline Phase & Conductivity & $\mathbf{N}$ & Mean rank & Chi-square & $p$-value \\
\hline \multirow[t]{6}{*}{ Adults } & 0.6 & 40 & 130.15 & 68.82 & $<0.001$ \\
\hline & 16 & 40 & 135.28 & & \\
\hline & 37 & 40 & 108.64 & & \\
\hline & 74 & 40 & 75.96 & & \\
\hline & 100 & 40 & 52.48 & & \\
\hline & Total & 200 & & & \\
\hline \multirow[t]{6}{*}{ Nymphs } & 0.6 & 40 & 130.46 & 87.37 & $<0.001$ \\
\hline & 16 & 40 & 142.70 & & \\
\hline & 37 & 40 & 101.34 & & \\
\hline & 74 & 40 & 64.00 & & \\
\hline & 100 & 40 & 64.00 & & \\
\hline & Total & 200 & & & \\
\hline \multirow[t]{6}{*}{ Eggs } & 0.6 & 40 & 137.38 & 82.14 & $<0.001$ \\
\hline & 16 & 40 & 137.05 & & \\
\hline & 37 & 40 & 104.44 & & \\
\hline & 74 & 40 & 78.14 & & \\
\hline & 100 & 40 & 45.50 & & \\
\hline & Total & 200 & & & \\
\hline
\end{tabular}


S1.2. Effects of species, conductivity and their interaction on upper thermal limit (UTL) and lower thermal limit (LTL) of different corixid species.

\begin{tabular}{lcccc}
\hline Effect & SS & df & $\boldsymbol{F}$ & $\boldsymbol{p}$ \\
\hline UTL (Heat coma) & & & & \\
Full model & 104562.421 & 7 & 12641.375 & $(<0.001)$ \\
Intercept & 312937.138 & 1 & 264834.0 & $(<0.001)$ \\
Conductivity & 34284.940 & 1 & 29014.835 & $(<0.001)$ \\
Species & 37489.286 & 3 & 10575.542 & $(<0.001)$ \\
Condutivity x species & 32788.195 & 3 & 9249.387 & $(<0.001)$ \\
Error & 255.233 & 216 & & \\
\hline LTL (Supercooling point) & & & & \\
Full model & 3906.711 & 7 & 135.980 & $(<0.001)$ \\
Intercept & 10661.880 & 1 & 2597.733 & $(<0.001)$ \\
Conductivity & 2017.200 & 1 & 491.484 & $(<0.001)$ \\
Species & 1038.862 & 3 & 84.372 & $(<0.001)$ \\
Condutivity x species & 850.690 & 3 & 69.086 & $(<0.001)$ \\
Error & 886.529 & 216 & & \\
\hline
\end{tabular}

S1.3. Effects of species, conductivity and their interaction on the oviposition rate of different corixid species.

\begin{tabular}{lcccc}
\hline Effect & SS & df & $\boldsymbol{F}$ & $\boldsymbol{p}$ \\
\hline Full model & 37.772 & 5 & 2.386 & $(0.050)$ \\
Intercept & 36.538 & 1 & 11.539 & $(0.001)$ \\
Conductivity & 0.693 & 1 & 0.219 & $(0.642)$ \\
Species & 32.303 & 3 & 3.400 & $(0.024)$ \\
Condutivity x species & 0.739 & 1 & 0.234 & $(0.631)$ \\
Error & 682.341 & 71 & & \\
\hline
\end{tabular}


S1.4. Effects of species, sex, and their interaction on wing loading (WL) and wing aspect ratio (WAR).

\begin{tabular}{llcccc}
\hline Test & Effect & SS & df & $\boldsymbol{F}$ & $\boldsymbol{p}$ \\
\hline \multirow{4}{*}{ WL } & Full model & 0.065 & 7 & 14.734 & $(<0.001)$ \\
& Intercept & 1.920 & 1 & 3036.395 & $(<0.001)$ \\
& Species & 0.024 & 3 & 12.813 & $(<0.001)$ \\
& Sex & 0.026 & 1 & 40.516 & $(<0.001)$ \\
& Species x sex & 0.015 & 3 & 8.062 & $(<0.001)$ \\
& Error & 0.071 & 112 & & \\
\hline \multirow{4}{*}{ WAR } & Full model & 0.787 & 7 & 14.267 & $(<0.001)$ \\
& Intercept & 524.908 & 1 & 66647.400 & $(<0.001)$ \\
Species & 0.685 & 1 & 28.978 & $(<0.001)$ \\
& Sex & 0.048 & 3 & 6.074 & $(0.015)$ \\
& Species x sex & 0.054 & 3 & 2.288 & $(0.082)$ \\
& Error & 0.882 & 216 & & \\
\hline
\end{tabular}

